\title{
CLINICAL AND EPIDEMIOLOGICAL ASPECTS OF HTLV-II INFECTION IN SÃO PAULO, BRAZIL: PRESENCE OF TROPICAL SPASTIC PARAPARESIS/HTLV-ASSOCIATED MYELOPATHY (TSP/HAM) SIMILE DIAGNOSIS IN HIV-1-CO-INFECTED SUBJECTS
}

\author{
Maria Paulina POSADA-VERGARA(1), Patrícia MONTANHEIRO(2), Ligia M.I. FUKUMORI(2), Francisco BONASSER(1), Alberto José da Silva DUARTE(2),
} Augusto Cesar PENALVA DE OLIVEIRA(1,3) \& Jorge CASSEB(1,2)

\begin{abstract}
SUMMARY
In this study, the epidemiological and clinical features observed in solely HTLV-II-infected individuals were compared to those in patients co-infected with HIV-1. A total of 380 subjects attended at the HTLV Out-Patient Clinic in the Institute of Infectious Diseases "Emilio Ribas" (IIER), São Paulo, Brazil, were evaluated every 3-6 months for the last seven years by infectious disease specialists and neurologists. Using a testing algorithm that employs the enzyme immuno assay, Western Blot and polymerase chain reaction, it was found that 201 (53\%) were HTLV-I positive and 50 (13\%) were infected with HTLV-II. Thirty-seven (74\%) of the HTLV-II reactors were co-infected with HIV-1. Of the $13(26 \%)$ solely HTLV-II-infected subjects, urinary tract infection was diagnosed in three (23\%), one case of skin vasculitis (8\%) and two cases of lumbar pain and erectile dysfunction (15\%), but none myelopathy case was observed. Among 37 co-infected with HIV-1, four cases (10\%) presented with tropical spastic paraparesis/ HTLV-associated myelopathy (TSP/HAM) simile. Two patients showed paraparesis as the initial symptom, two cases first presented with vesical and erectile disturbances, peripheral neuropathies were observed in other five patients (13\%), and seven (19\%) patients showed some neurological signal or symptoms, most of them with lumbar pain (five cases). The results obtained suggest that neurological manifestations may be more frequent in HTLV-II/HIV-1-infected subjects than those infected with HTLV-II only.
\end{abstract}

KEYWORDS: HTLV-II, HIV-1; Co-infection; Neurological manifestation; TSP/HAM simile.

\section{INTRODUCTION}

Human T cell lymphotropic virus type 2 (HTLV-II) shares $65 \%$ of its nucleotide sequences with human $\mathrm{T}$ cell lymphotropic virus type 1 $(\text { HTLV-I })^{12}$. HTLV-II has not been etiologically linked with any disease, although a number of case reports and a few cross-sectional studies suggest an association with a tropical spastic paraparesis/HTLVassociated myelopathy (TSP)-like syndrome ${ }^{4,17}$. In addition, other manifestations such as pneumonia, bronchitis and urinary tract infection have been associated to HTLV-II infection ${ }^{18}$.

HTLV-II infection is presented among intravenous drug users (IDU), HIV-1-infected patients, and some Amerindian tribes ${ }^{1}$. As HIV-1 and HTLV-II share similar routes of transmission, mainly sexual and intravenous drug use, and several individuals may harbor the two viruses at the same time ${ }^{6,10}$. In Brazil, HTLV-II infection may account for $10 \%$ of the HIV-infected population, usually the IDU in urban areas ${ }^{2,9}$. More recently, HTLV-II infection can be found in HCV infected subjects ${ }^{20}$. No observational studies of neurological manifestation either in HTLVII or co-infected with HIV-1-infected individuals have been related in São Paulo, Brazil. In this study, four cases of myelopathy in HTLV-II/
HIV-1 co-infected subjects were described.

\section{MATERIAL AND METHODS}

A total of 380 individuals referred to the HTLV Out-Patient Clinic at the Institute of Infectious Diseases "Emílio Ribas" (IIER) from June 1997 to June 2004 were evaluated every 3-6 months. HTLV-I or -II infection was detected by enzyme immunoassay (HTLV-I and HTLVIl capture EIA, Ortho Diagnostics System Inc. Raritan, NJ, USA) and confirmed and typed by Western-Blot (WB HTLV 2.4, GeneLabs Diagnostics, Singapore) and/or polymerase chain reaction (PCR) for pol region. Both assays were done in accordance with standard protocol $^{22}$. The HCV diagnosis was done by serological tests and confirmed by qualitative PCR, both performed in the clinical routine laboratory.

Lymphocyte $\mathrm{T}$ cell counts were measured by flow cytometry (XL Model, Beckman Coulter, Inc., Fullerton, California, USA). Following written informed consent, patients underwent a neurological evaluation by a neurologist, who was blinded to the HTLV status of the patients. Patients who have at least two pyramidal signs, such as paresis, 


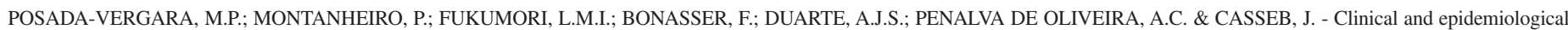
aspects of HTLV-II infection in São Paulo, Brazil: presence of Tropical Spastic Paraparesis/HTLV-Associated Myelopathy (TSP/HAM) simili diagnosis in HIV-1-co-infected subjects. Rev. Inst. Med. trop. S. Paulo, 48(4): 207-210, 2006.

hypertonicity or spasticity, hyperreflexia, clonus, diminished or absent superficial reflexes, or the presence of pathological reflexes (e.g., Babinsky, Hoffmann, or Trömner signals), were diagnosed as having myelopathy. It was excluded potential differential diagnosis such B12 deficiency, syphilis, thyroid dysfunction, or spinal cord compression ${ }^{18}$. Incapacity and functional disability scale (FDS), from a modified Kurtzke Disability Status Scale (EDSS) was used to grade the severity of motor symptoms of myelopathy ${ }^{3}$.

In the first visit, a signed informed consent was obtained from all participants and a personal interview was performed to fill up a questionnaire. Every visit, one clinical and physical examination was done, and all informations were included in the database (Epi-Info, version 6.4). The statistical analysis was done using statistical Cal software and the chi-square was calculated by Fisher's exact test or by Kruskal-Wallis' test and the $\mathrm{p}$ value was considered significant when $<0.05$, two-sided.

\section{RESULTS}

Two hundred one $(53 \%)$ of the 380 subjects were HTLV-I-infected and $50(13 \%)$ were HTLV-II infected. Thirty-seven (74\%) of the HTLVII-infected subjects were also co-infected with HIV-1. In the 13 (26\%) solely HTLV-II-infected subjects (nine women and four men), the mean age was $38 \pm 12$ years, the major risk for HTLV-II group was sexual risk, only two cases were IDU ( $p=0.0005$, Fisher's exact test). Among the 50 co-infected patients, $26(70 \%)$ were males, and $28(76 \%)$ were IDU. Similarly, HCV infection was more likely to occur in the coinfected group ( $\mathrm{p}=0.005$, Fisher's exact test). As expected, the $\mathrm{CD} 4^{+}$ $\mathrm{T}$ cell counts were lower in the HTLV-II/HIV-1 co-infected subjects ( $\mathrm{p}$ $=0.01$, Kruskal-Wallis' test). Demographical, laboratorial, and clinical data of the HTLV-II-infected cases are summarized in Table 1.

Among 13 solely HTLV-II-infected subjects, urinary tract infection was diagnosed in three $(26 \%)$ and there was one $(8 \%)$ case of skin vasculitis. Two patients presented with lumbar pain and erectile dysfunction (15\%). No myelopathy case was observed. In contrast, among the 37 co-infected with HIV-1, four (10\%) cases presented with TSP/HAM simile. Two of them showed paraparesis as the initial symptom and the other two initially presented with vesical and erectile disturbances. Peripheral neuropathies were observed in five patients
(13\%). Other seven (19\%) patients showed some neurological signals or symptoms, mostly lumbar pain (five cases). below:

The four TSP/HAM co-infected HIV-1/HTLV-II cases are presented

Patient 1: A 54-year-old homosexual male who presented neurological symptoms in April 1997, when he showed reactivity for HIV-1 antibodies. He denied any symptoms before that occasion. $\mathrm{He}$ had progressive walking impairment, with wheelchair outcome in June 1997, along with urinary and impotence disturbances. In July, because of his $\mathrm{CD}^{+} \mathrm{T}$ cell count $\left(271\right.$ cells $\left./ \mathrm{mm}^{3}\right)$, he was started on antiretroviral therapy (ARV therapy) with zidovudine (AZT), lamivudina (3TC), and ritonavir. After three months of ARV therapy, he recovered from urinary symptoms and he could walk with a walker. At this time, his $\mathrm{CD}^{+} \mathrm{T}$ cell count was 267 cells/mm $\mathrm{mm}^{3}$ and HIV-1 RNA load was 45,000 copies/ $\mathrm{mL}$. Nine months later, he was able to walk independently and there was a slight bladder dysfunction (FDS from 5 to 2). Even though he was seronegative for HTLV antibodies, the PCR for HTLV-II was positive on two different occasions.

Patient 2: 33 year-old male, an ex-IDU who was found to have an HIV-1-infection in 1997. On this occasion, he had difficulties for walking, with wheelchair outcome in October 97, when he started with AZT, 3TC and indinavir. In March 98, at the first neurological evaluation, he was able to walk with a walker. After 18 months of ARV he was able to walk with a cane (FDS from 5 to 3 ), and the $\mathrm{CD}^{+} \mathrm{T}$ cell count rose from 01 cell to 771 cells $/ \mathrm{mm}^{3}$ and the RNA viral load decreased from 130,000 copies/mL to less than 80 copies $/ \mathrm{mL}$ in October 1999. Both WB and PCR revealed HTLV-II infection.

Patient 3: a 31 year-old male, was an ex-IDU, with HIV-1 and HCV infections. He showed clinical features of TSP/HAM in 2001, including sexual dysfunction erection. His $\mathrm{CD}^{+}{ }^{+} \mathrm{T}$ cell count was 677 in 2000 with a viral load of less than 400 copies/mL. He never used $\mathrm{ARV}$ and has been asymptomatic for HIV and HCV infections. Unfortunately, his follow up was lost. The WB profile revealed HTLVII infection.

Patient 4: a 38-year-old ex-IDU male, who was infected with HIV1, HCV and HTLV-II. He developed TSP/HAM-like symptoms (it may

Table 1

Demographic, laboratorial and clinical data of 50 human T-cell lymphotropic virus type 2 (HTLV-II)-infected subjects at the baseline, evaluated at HTLV Out-Patient Clinic of Infectious Diseases Institute, São Paulo City, SP, Brazil, from June 1997 to June 2004

\begin{tabular}{|c|c|c|c|}
\hline Variable & $\begin{array}{l}\text { HTLV-II-infected solely } \\
\qquad(\mathrm{n}=13)\end{array}$ & $\begin{array}{l}\text { HTLV-II/HIV-1- co-infected } \\
\qquad(\mathrm{n}=37)\end{array}$ & $\mathrm{p}$ value \\
\hline Gender ratio $(\mathrm{M} / \mathrm{F})^{*}$ & $4 / 9$ & $26 / 11$ & $0.03 *$ \\
\hline Age $($ Mean $\pm \mathrm{SD}) /$ years* & $38 \pm 12$ & $36 \pm 8$ & $0.09 *$ \\
\hline IDU risk $\mathrm{n}(\%)^{*}$ & $2(15)$ & $28(76)$ & $0.0005^{*}$ \\
\hline $\operatorname{HCV}$ n $(\%)^{*}$ & $2(15)$ & $24(65)$ & $0.006^{*}$ \\
\hline $\mathrm{CD}^{+} \mathrm{T}\left(\text { cells } / \mathrm{mm}^{3}\right)^{* *}($ mean $\pm \mathrm{SD})$ & $1003 \pm 376$ & $417 \pm 369$ & $<0.01 * *$ \\
\hline $\mathrm{CD}^{+} \mathrm{T}\left(\text { cells } / \mathrm{mm}^{3}\right)^{* *}($ mean $\pm \mathrm{SD})$ & $535 \pm 215$ & $897 \pm 537$ & $0.004 * *$ \\
\hline Myelopathy & 0 & 4 & $0.5^{*}$ \\
\hline
\end{tabular}

*Fisher's exact test; ** Kruskal-Wallis' test; $\mathrm{M}=$ male; $\mathrm{F}=$ Female; $\mathrm{SD}=$ Standard deviation; IDU: intravenous drug user; HCV = hepatitis $\mathrm{C}$ virus. 


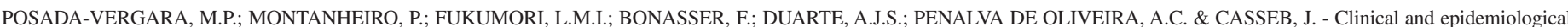
aspects of HTLV-II infection in São Paulo, Brazil: presence of Tropical Spastic Paraparesis/HTLV-Associated Myelopathy (TSP/HAM) simili diagnosis in HIV-1-co-infected subjects. Rev. Inst. Med. trop. S. Paulo, 48(4): 207-210, 2006.

be vacuolar myelopathy) in March 2001. His incapacity scale was seven, and his follow up was lost. HTLV-II infection was observed in the WB profile and PCR.

\section{DISCUSSION}

HTLV-II-infection was more common in women (2:1 ratio) among HIV-uninfected subjects. Whereas, this infection was more frequently in males during the co-infection with HIV-1. This finding can be explained by the high prevalence of HCV co-infection with HIV in IDU $(\sim 70 \%)$, in contrast in solely HTLV-II-infected subjects, where only $\sim 20 \%$ with anti-HCV antibodies were found. These observations probably reflect the routes of transmissions, since among women, the major route for HTLV-II infection was heterosexual partner relationship or being Indians descendents, and among the HIV-1-infected subjects were basically IDU (data not shown). Taken together, these data indicate that use of intravenous drug is the most potential mode of transmission of these viruses. The high co-existence of HTLV-II and HCV in this host may have important clinical and epidemiological implications in this population. New evidences show that HTLV-II/HIV-1 coinfection may be harmful for the host. In fact, the role of HTLV-II infection interaction with $\mathrm{HCV}$ on liver damage should be better investigated since HTLV-I/HCV patients present worse prognosis for cirrhosis and hepatocarcinoma ${ }^{8}$ or higher $\mathrm{HCV}$ viral load ${ }^{11}$.

The $\mathrm{CD}^{+}$and $\mathrm{CD}^{+}{ }^{+} \mathrm{T}$ cells counts in the single HTLV-II infection were normal; in contrast, in the HIV-1/HTLV-II co-infected group, CD4 ${ }^{+}$ $\mathrm{T}$ cell counts were lower and the $\mathrm{CD} 8^{+} \mathrm{T}$ cell count were higher. These findings may reflect the immune pathogenesis of HIV-1-infection, where HIV leads to $\mathrm{CD} 4^{+} \mathrm{T}$ cells destruction and the immune activation causes increasing of $\mathrm{CD}^{+} \mathrm{T}$ cells during infection. On basis of the clinical findings, some HTLV-II-infected subjects showed peripheral neuropathy during the co-infection and urinary tract infection either in HIV-1/HTLV-II-infected subjects as well in solely infected with HTLVII. These findings have been shown by other investigators ${ }^{2,23}$, but its pathogenesis remain to be better studied.

Risk for TSP/HAM development is less than $1 \%$ after decades of incubation period among the HTLV-I-infected individuals ${ }^{13}$. It has been described that HTLV-II also may account for some unique cases ${ }^{14,16,18,21}$. Thus, the cases reported in this study may represent a common feature in the HIV/AIDS epidemic in countries where these two retroviruses are highly endemic, as is the case of Brazil. In fact, the high prevalence was first described in developed countries ${ }^{5}$. In addition, only one case of vacuolar myelopathy was diagnosed in the last years among single HIV-1-infected subjects in a cohort of 240 HIV-infected subjects who have been followed up at the Hospital das Clinicas in São Paulo city since 1989 (data not shown).

Despite no TSP/HAM simile case or other neurological syndromes were observed on solely HTLV-II infection in the cohort evaluated in this study, other groups in South America have described such cases $^{6,7,15,21}$. There are some clinical and laboratorial data that suggest that HTLV-II infection induces the myelopathy process during coinfection with HIV- $1^{5}$, since the major differential diagnosis should be done with vacuolar myelopathy ${ }^{19}$. Despite that, only spinal cord histological findings could be addressed in this issue, usually vacuolar myelopathy in HIV-1-infected patients may occur without cognitive damage (dementia) and low $\mathrm{CD} 4^{+} \mathrm{T}$ cell count ${ }^{19}$. It was noted that clinical improvement of TSP/HAM symptoms after ARV and this finding deserves further investigation. Furthermore, other etiologies should be ruled out such as infections, expansive lesions, vitamin B12 deficiency and other metabolic disturbances.

\section{RESUMO}

Aspectos clínicos e epidemiológicos da infecção pelo vírus linfotrópico de células T humanas do tipo 2 (HTLV-II) em São

Paulo, Brasil: presença de paraparesia espástica tropical/ mielopatia associada ao HTLV em pacientes co-infectados pelo HIV-1

Neste estudo, as características epidemiológicas e clínicas observadas nos indivíduos infectados pelo HTLV-II foram comparadas com os pacientes co-infectados com HIV-1. Um total de 380 indivíduos atendidos na clínica do Ambulatório HTLV do Instituto de Infectologia "Emilio Ribas" (IIER), São Paulo, Brasil, foram avaliados a cada 3-6 meses nos últimos sete anos por especialistas em doenças infecciosas e neurologistas. Usando um algoritmo que emprega ensaio imunoenzimático, Western Blot e reação em cadeia de polimerase, foram incluídos 201 (53\%) pacientes infectados pelo HTLV-I e 50 (13\%) infectados pelo HTLV-II. Trinta e sete (74\%) eram co-infectados pelo HTLV-II e HIV-1. Dos 13 (26\%) indivíduos unicamente infectados pelo HTLV-II, infecção do trato urinário foi diagnosticada em três, um com vasculite e em dois casos dor lombar e disfunção erétil mas nenhum caso de mielopatia foi observado. Entre 37 pacientes co-infectados com HIV-1, quatro (10\%) casos apresentaram com paraparesia espástica tropical/mielopatia associada ao HTLV similar. Dois casos mostraram paraparesia como sintoma inicial, dois outros casos se apresentaram primeiramente com distúrbios vesical e erétil e as neuropatias periféricas foram observadas em cinco pacientes (13\%). Outros sete (19\%) pacientes mostraram algum sinal ou sintoma neurológico, a maioria deles com dor lombar (cinco casos). Os resultados sugerem que as manifestações neurológicas podem ser mais freqüentes em indivíduos co-infectados pelo HTLV-II/HIV-1 do que nos indivíduos infectados somente pelo HTLV-II.

\section{ACKNOWLEDGEMENTS}

The authors thank Dana Gallo for the helpful discussion, all the patients who participated in this study, the anonymous revisers, and the financial support provided by Fapesp 99/11188-1, 03/08901-5, ${ }^{\circ}$ 03/00841-3, CNPq, FFM.

\section{REFERENCES}

1. ARAUJO, A. \& HALL, W.W. - Human T-lymphotropic virus type II and neurological disease. Ann. Neurol., 56: 10-19, 2004.

2. ARAUJO, A.; SHEEHY, N.; TAKAHASHI, H. \& HALL, W.W. - Concominant infections with human immunodeficiency virus 1 and human T-lymphotropic virus types 1 and 2. In: BROGDEN, K.A. \& GUTHMILLER, J.M. Polymicrobial diseases. Washington, ASM Press, 2002.

3. BALCER, L.J. - Clinical outcome measures for research in multiple sclerosis. J. Neuroophthalmol., 21: 296-301, 2001 


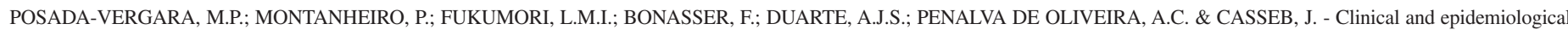
aspects of HTLV-II infection in São Paulo, Brazil: presence of Tropical Spastic Paraparesis/HTLV-Associated Myelopathy (TSP/HAM) simili diagnosis in HIV-1-co-infected subjects. Rev. Inst. Med. trop. S. Paulo, 48(4): 207-210, 2006.

4. BEILKE, M.A.; GREENSPAN, D.L.; IMPEY, A.; THOMPSON, J. \& DIDIER, P.J. Laboratory study of HIV-1 and HTLV-I/ll co-infection. J. med. Virol., 44: 132-143, 1994.

5. BERGER, J.R.; SVENNINGSSON, A.; RAFFANTI, S. \& RESNICK, L. - Tropical spastic paraparesis-like illness occurring in a patient dually infected with HIV-1 and HTLV11. Neurology, 41: 85-87, 1991.

6. BIGLIONE, M.M.; PIZARRO, M.; SALOMON, H.E. \& BERRIA, M.I. - A possible case of myelopathy/tropical spastic paraparesis in an Argentinian woman with human T lymphocyte virus type II. Clin. infect. Dis., 37: 456-458, 2003.

7. BLACK, F.L.; BIGGAR, R.J.; LAL, R.B.; GABBAI, A.A. \& FILHO, J.P. - Twenty-five years of HTLV type II follow-up with a possible case of tropical spastic paraparesis in the Kayapo, a Brazilian Indian tribe. AIDS Res. hum. Retrovir., 12: 1623-1627, 1996.

8. BOSCHI-PINTO, C.; STUVER, S.; OKAYAMA, A. et al. - A follow-up study of morbidity and mortality associated with hepatitis $\mathrm{C}$ virus infection and its interaction with human T lymphotropic virus type I in Miyazaki, Japan. J. infect. Dis., 181: 35-41, 2000.

9. DE ARAUJO, A.C.; CASSEB, J.S.; NEITZERT, E. et al. - HTLV-I and HTLV-II infections among HIV-1 seropositive patients in São Paulo, Brazil. Europ. J. Epidem., 10: $165-171,1994$

10. ETZEL, A.; SHIBATA, G.Y.; ROZMAN, M. et al. - HTLV-1 and HTLV-2 infections in HIV-infected individuals from Santos, Brazil: seroprevalence and risk factors. J. acquir. immune Defic. Syndr., 26: 185-190, 2001.

11. HISADA, M.; CHATTERJEE, N.T.; ZHANG, M.; BATTJES, R.J. \& GOEDERT, J.J. Increased hepatitis $C$ virus load among injection drug users infected with human immunodeficiency virus and human T lymphotropic virus type II. J. infect. Dis., 188: 891-897, 2003.

12. LOWIS, G.W.; SHEREMATA, W.A. \& MINAGAR, A. - Epidemiologic features of HTLVII: serologic and molecular evidence. Ann. Epidem., 12: 46-66, 2002.

13. MATSUZAKI, T.; NAKAGAWA, M.; NAGAI, M. et al. - HTLV-I proviral load correlates with progression of motor disability in HAM/TSP: analysis of $239 \mathrm{HAM} / \mathrm{TSP}$ patients including 64 patients followed up for 10 years. J. Neurovirol., 7: 228-234, 2001.
14. PETERS, A.A.; OGER, J.J.; COULTHART, M.B. et al. - An apparent case of human Tcell lymphotropic virus type II (HTLV-II)-associated neurological disease: a clinical, molecular, and phylogenetic characterisation. J. clin. Virol., 14: 37-50, 1999.

15. MENNA-BARRETO M. - The progression of disability in HTLV-II-associated myelopathy. Europ. J. Neurol., 10(suppl. 1): 13, 2003.

16. MURPHY, E.L.; FRIDEY, J.; SMITH, J.W. et al. - HTLV-associated myelopathy in a cohort of HTLV-1 and HTLV-11 infected blood donors. Neurology, 48: 315-320, 1997.

17. MURPHY, E.L.; WANG, B.; SACHER, R.A. et al. - Respiratory and urinary tract infections, arthritis, and asthma associated with HTLV-I and HTLV-1l infection. Emerg. infect. Dis., 10: 109-116, 2004.

18. ORLAND, J.R.; ENGSTROM, J.; FRIDEY, J. et al. - Prevalence and clinical features of HTLV neurologic disease in the HTLV outcomes study. Neurology, 61: 1588-1594, 2003.

19. PETITO, C.K.; NAVIA, B.A.; CHO, E.S. et al. - Vacuolar myelopathy pathologically resembling subacute combined degeneration in patients with acquired immunodeficiency syndrome. New Engl. J. Med., 312: 874-879, 1985.

20. SEGURADO, A.C.; BRAGA, P.; ETZEL, A. \& CARDOSO, M.R. - Hepatitis C virus coinfection in a cohort of HIV-infected individuals from Santos, Brazil: seroprevalence and associated factors. AIDS Patient Care STDS, 18: 135-143, 2004.

21. SILVA, E.A.; OTSUKI, K.; LEITE, A.C. et al. - HTLV-II infection associated with a chronic neurodegenerative disease: clinical and molecular analysis. J. med. Virol., 66: $253-257,2002$

22. TUKE, P.W.; LUTON, P. \& GARSON, J.A. - Differential diagnosis of HTLV-I and HTLVII infections by restriction enzyme analysis of 'nested' PCR products. J. virol. Meth., 40: $163-173,1992$.

23. ZEHENDER, G.; COLASANTE, C.; SANTAMBROGIO, S. et al. - Increased risk of developing peripheral neuropathy in patients coinfected with HIV-1 and HTLV-2. J. acquir. immune Defic. Syndr., 31: 440-447, 2002.

Received: 13 December 2005

Accepted: 18 April 2006 